\title{
INVESTMENT IN EDUCATION AS A KEY DETERMINANT OF AGRICULTURAL INSURANCE GROWTH
}

Sofija Adzic, Dragan Stojic, University of Novi Sad, stojicd@ef.uns.ac.rs

The main objective of this paper is to examine the impact of education, on decision to purchase insurance. We measure the impact of education both through years of formal education and capital invested in research and development. The focus is on insurance in agriculture, due to the fact that Serbia, and it's prominent province of Vojvodina possess mainly agricultural lands. We use regression method incorporating several macro-economic variables as control variables: GDP per capita, index of economic freedom, foreign direct investments and private sector credit, to name few. Main results indicate significant and positive influence of education, as the educational elasticity of demand for insurance is significantly higher than one.

JEL Classification Numbers: C33, G22, Q12, DOI: 10.12955/cbup.2013.23

Key words: agriculture, insurance, human capital

\section{Introduction}

Agricultural production has an enormous social and economic impact on Serbia. In the year of 2010 it's share in GDP was $10.6 \%$, i.e. $21.9 \%$ when food industry production included. It employed $23 \%$ of the total working force, which equals to $17 \%$ of active population, while it's share in total export mounted to 23.3\%. According to the World Bank Indicators online (World Bank, 2013), the share of agriculture in total value added to GDP was $34 \%$. Due to favorable climatic conditions, large arable areas per capita and proximity to EU market, the agribusiness of Serbia has got a decent potential for further development. However, agricultural production faces multiple risks, including natural disasters, extreme weather conditions, uncertain future prices and yields, etc.

\section{Literature review}

The development of Serbian insurance industry was marked by general economic development. Even though insurance market had existed prior to WWII, it gained momentum in 1990 when new insurance law was adopted enabling the foundation of insurance companies based on market economy principles. However, inadequate auditing and regulation led to proliferation of insurance companies with dubious management practice, and finally complete loss of insurance funds during hyperinflation in 1993. Public trust in insurance in general was lost, and that included agricultural insurance as well. Things changed for better for Serbian insurance in 2004 when the new Insurance law was adopted, while the auditing function was passed onto Serbian national bank (NBS). The change in regulation and supervision finally created long needed order, which led to significant decrease in number of insurance companies from 38 in June of 2004 to 17 at the end of 2006. From 2004 we observe 
continuous increase in premia collected denoting the slow regain of confidence in insurance system. Descriptive statistics is given in Table 1. For more information on Serbian, and more general, Eastern European insurance market see e.g. Njegomir and Stojic (2012).

\begin{tabular}{|c|c|c|c|c|c|c|c|c|c|}
\hline & & 2004 & 2005 & 2006 & 2007 & 2008 & 2009 & 2010 & 2011 \\
\hline \multirow{3}{*}{$\begin{array}{l}\text { Crop } \\
\text { insurance }\end{array}$} & $\begin{array}{l}\text { Premium } \\
\text { collected }\end{array}$ & 578262 & 611733 & 611691 & 751461 & 1105208 & 746736 & 796873 & 968926 \\
\hline & $\begin{array}{l}\text { Annual } \\
\text { growth }\end{array}$ & - & $5.79 \%$ & $-0.01 \%$ & $22.85 \%$ & $47.07 \%$ & $-32.43 \%$ & $6.71 \%$ & $21,59 \%$ \\
\hline & $\begin{array}{l}\text { Number of } \\
\text { contracts }\end{array}$ & 10396 & 9418 & 9351 & 10305 & 15186 & 10165 & 11172 & 11548 \\
\hline \multirow{3}{*}{$\begin{array}{l}\text { Animal } \\
\text { insurance }\end{array}$} & $\begin{array}{l}\text { Premium } \\
\text { collected }\end{array}$ & 259748 & 328554 & 409737 & 516619 & 511247 & 377500 & 283180 & 269200 \\
\hline & $\begin{array}{l}\text { Annual } \\
\text { growth }\end{array}$ & - & $26.49 \%$ & $24.71 \%$ & $26.09 \%$ & $-1.04 \%$ & $-26.16 \%$ & $-25 \%$ & $-4,94 \%$ \\
\hline & $\begin{array}{l}\text { Number of } \\
\text { contracts }\end{array}$ & 2299 & 2396 & 2278 & 2582 & 2250 & 1807 & 1212 & 1487 \\
\hline \multicolumn{2}{|c|}{$\begin{array}{l}\text { Participation of crop } \\
\text { insurance in total } \\
\text { agricultural insurance }\end{array}$} & $69.00 \%$ & $65.06 \%$ & $59.89 \%$ & $59.26 \%$ & $68.37 \%$ & $66.42 \%$ & $73.78 \%$ & $78.26 \%$ \\
\hline \multicolumn{2}{|c|}{$\begin{array}{l}\text { Participation of } \\
\text { agricultural insurance } \\
\text { total non-life insurance }\end{array}$} & $4.00 \%$ & $3.00 \%$ & $2.98 \%$ & $3.18 \%$ & $3.53 \%$ & $2.46 \%$ & $2.29 \%$ & $2.62 \%$ \\
\hline \multicolumn{10}{|c|}{ Source: Statistical Yearbook of Serbia (2012) and authors' calculations } \\
\hline
\end{tabular}

Agricultural insurance in Serbia is undeveloped when compared to certain countries: e.g. in the year 2008 insurance premium per hectare in the US was $\$ 60, \$ 13.38$ in China, while only $\$ 3.45$ in Serbia. We argue that the main causes of underdevelopment (beside low purchasing power) is an insufficient awareness of necessity and possibilities of risk management, as well as focusing on every-day perils which are highly frequent, yet low in intensity and damage produced. Even though government subsidies do exist at the level of $40 \%$ of premium paid, it is still less than their level in surrounding countries (e.g. up to $75 \%$ in Croatia and $60 \%$ in Macedonia) and applicable only in certain cases. However, the impact of subsidies is thought to have a positive impact on agricultural insurance (see e.g. Njegomir and Pejanovic, 2011; Pejanovic and Njegomir, 2011). Only 10\% of farmers actually choose to insure.

Most think that insurance incurs high costs, especially when premiums are paid before revenues from crops have been collected. All insurance laws passed until now have made agricultural insurance voluntary; hence the insurance purchasing 'habit' has never been developed. However, we observe an increase in premiums after drought, or flooding. In general, perceptions of vulnerability, teamed with a high degree of experience with a prior disaster, prove to be a powerful predictor of whether individuals will prepare for the next occurrence (Palm and Hodgson, 1992; Blanchard-Boehm, 1995). This hypothesis was supported as early as the mid-1960s by Burton and Kates (1964), who observed that in areas where recurrence is rare and less predictable, individuals are not likely to undertake steps towards preparedness and mitigation. This view is supported by Montz (1982) and Epple and Lave 
(1988), who also find that people occupying floodplains where flooding is not frequent may lack experience of such events.

The efficiency of intellectual capital is a fundamental indicator which is obtained by adding up efficiency of human (HCE) and structural capital (SCE). Lee (2010) defines the efficiency of human capital as a ratio of total information turned into profit. As the amount of information exchanged in each enterprise is unavailable, without diminishing the importance of Lee's theoretical approach, we opt for previously stated definition that uses data from financial statements. The following methodology was taken from Pulic (2003). HCE measures the amount of added value $(V A)^{1}$ created on each monetary unit invested in the employees. Structural capital $S C=V A-H C$ is a result of human labor in the past and its efficiency is embodied as a share of created added value:

$I C E_{i}=V A_{i} / B P Z_{i}+S C_{i} / V A_{i}$. According to Pulic (2003), the highly efficient enterprises $(I C E>2,5)$ are supposed to be able to generate additional profits more easily. Intellectual capital produces value in conjunction with physical and financial capital. The efficiency of physical capital usage, $C E E$ represents the share of added value in total assets $(T A)$ of an enterprise:

$C E E=V A / T A$. $C E E$ exhibits the amount of created added value by each monetary unit invested in physical capital.

Recent practice in economics has been estimating human capital on the basis of years of schooling or formal educational attainment levels, regardless of actual productive capacity. Barro and Lee (2001) provide prominent examples on this subject. At the micro level there is consistent evidence that education raises incomes significantly, yet evidence at the macro level has been mixed. Studies such as Barro (1991), Bils and Klenow (2000), Mankiw et al. (1992) and others use enrollment rates for primary and secondary education and point toward a positive and significant effect. For detail insight to Serbian education and labor market please refer to Adzic et al. (2013).

The role of education on consumer behavior on the insurance market is well documented. Education is interactive with other occupational characteristics. Dewar (1998) showed that there exists a direct association between formal educational attainment and returns from employment. Also persons with less formal education have a decreased access to insurance. Ioncica et al. (2012) argue that low interest in purchasing insurance is due to misunderstanding the role and necessity of insurance, caused by the lack of education. Authors also point out that risk assessment is often done intuitively and that new methods of learning and communication facilitate the process of education.

\section{Data and methodology}

Inflation rate, population and GDP data are obtained from European Bank for Research and Development (EBRD) economic statistics and forecasts published for each year in Transition Report. This paper investigates to which extent we can apply previous studies in terms of identifying factors that influence the decision to purchase agricultural insurance. We observe 80 farms in the agricultural region of Vojvodina, Serbia. Using data from Serbian Business Registers Agency ${ }^{2}$ we obtained

\footnotetext{
${ }^{1}$ The added value of an enterprise is calculated using formula $D P O+B P Z+A+D$, where $D P O$ denotes profit before taxation, $B P Z$ gross workers' salaries and other workers' expenses, $A$ is amortization, and $D$ is depreciation.

${ }^{2}$ http://pretraga2.apr.gov.rs/ObjedinjenePretrage/Search/Search
} 
financial statements for each farm and also the number of employees, and for each employee the number of years engaged in formal education. Each enterprise was asked to fill the questionnaire concerning insurance data: total premium (if any) paid per year for crop insurance, and per animal insured. In order to make those values comparable between enterprises we observe the total premium per employee. As odd as it may seem, we opt for this measure in order to capture the size of the insurance paid by each employee. We argue that this variable is positively correlated with both years of formal education of employees, as well as human capital efficiency, which will serve as two main explanatory variables. We also include a dummy variable denoting the size of the company: zero if small, one if medium. We apply firm-specific effects for panel data regression. Other independent variables include macroeconomic indicators such as GDP per capita as a measure of overall state of economy.

The general equation to be estimated is:

$y_{i t}=\alpha_{i}+x_{i t} \beta+u_{i t}$,

where $y_{i t}$ is a scalar dependent variable, i.e. premium per employee (in log form), $x_{i t}$ is a $\mathrm{K} \times 1$ vector of independent variables, $u_{i t}$ is a scalar disturbance term, $\mathrm{i}$ indexes the farm in a cross section, and $\mathrm{t}$ indexes time measured in years.

\section{Results}

All-time series were tested for stationarity. Seven dummy variables for each year were introduced in the model for dealing with time effects directly (variable $y_{05}$ taking value 1 for each enterprise in 2005, and 0 otherwise). The model was specified with individual effects, and Table 2 represents Hausman test for dismissing the hypothesis of individual random effects.

Table 2: Correlated Random Effects (Hausman Test)

\begin{tabular}{|l|l|l|l|l|}
\hline \multirow{4}{*}{} & \multicolumn{4}{|l|}{ Test cross-section random effects } \\
\cline { 2 - 5 } & Test Summary & Chi-Sq. & Chi-Sq. d.f. & Prob. \\
\cline { 2 - 4 } & Cross-section random & 18.622 & 6 & 0.005 \\
\hline
\end{tabular}

The final version includes only the significant year dummies. To control for a possible conjoint effect of education and intellectual capital efficiency the interaction term between two variables had been added. Table 3 represents the output of the regression equation.

First of all, we observe that all relevant variables have a 'correct' sign. Due to high number of observation, individual effects have been omitted and are available on request. GDP per cap has got a positive and significant influence on decision to buy agricultural insurance. That is in line with previous studies that use this variable as a proxy for insurance demand (e.g. Moshirian, 1999; Ma \& Pope, 2003; Outreville, 2008).

The average years spent in formal education have also a positive and significant influence on insurance premium; however the size of coefficient is less than predicted. The possible explanation lies in the fact that during the period of observation, agribusiness in Serbia suffered severe job losses, $47 \%$ for unskilled workers and those with elementary school, and 33\% for employees holding 
university diploma. Thus, we observe the increase in average educational attainment not by employing more skilled workers, but by firing more undereducated.

\begin{tabular}{|c|c|c|c|c|}
\hline \multicolumn{5}{|c|}{ Table 3: Panel regression results } \\
\hline \multicolumn{5}{|c|}{ Dependent Variable: LOG(AP) } \\
\hline \multicolumn{5}{|c|}{ Method: Panel EGLS (Cross-section weights) } \\
\hline \multicolumn{5}{|c|}{ Cross-sections included: 80} \\
\hline \multicolumn{5}{|c|}{ Total panel observations: 543} \\
\hline \multicolumn{5}{|c|}{ Linear estimation after one-step weighting matrix } \\
\hline Variable & Coefficient & Std. Error & t-Statistic & Prob. \\
\hline$C$ & $2.593 * * *$ & 0.437 & 5.931 & 0.000 \\
\hline$L O G(G D P)$ & $0.106^{* *}$ & 0.053 & 1.998 & 0.046 \\
\hline$L O G(E D U)$ & $0.027^{*}$ & 0.015 & 1.866 & 0.063 \\
\hline SIZE & -0.019 & 0.297 & -0.063 & 0.950 \\
\hline$Y_{08}$ & $0.125 * * *$ & 0.022 & 5.727 & 0.000 \\
\hline$Y_{11}$ & $0.067 * * *$ & 0.021 & 3.240 & 0.001 \\
\hline ICE & $0.018^{* * *}$ & 0.005 & 3.630 & 0.000 \\
\hline$L O G(E D U) * I C E$ & $0.014 * * *$ & 0.003 & 4.440 & 0.000 \\
\hline R-squared & 0.344 & \multicolumn{2}{|c|}{ Durbin-Watson stat } & 1.408 \\
\hline
\end{tabular}

Size of firms appears to be unimportant when observing the premium per employee. Intellectual capital efficiency has a positive and significant impact on decision to buy insurance. That comes with no surprise, since companies which are more efficient manage to generate more added value (Pulic, 2003), and reach for insurance as means of preserving their extra profit.

Two-year dummies that are significant are in line with Palm and Hodgson (1992), and BlanchardBoehm (1995) and represent the increase in premia paid after the occurrence of 'rare' events, such as hail, that hit Serbian fields in 2007. Also, drought in 2010 caused premia to rise in the next year.

We argue that imposing obligatory insurance would have beneficiary effect in terms of prompt reactions (without a year lag). Finally, the interaction term between years of schooling and intellectual capital gives an additional momentum in deciding to buy agricultural insurance.

\section{Conclusion}

Insurance is most widely used means of risk management in crop production in Serbia. Private insurance sector should be the most prominent in providing indemnification, while the role of the state should be limited to creating favorable regulatory and institutional environment for private initiative.

For the future research we shall investigate what would be the implications of the introduction of obligatory agricultural insurance. It would also benefit to isolate a time series with the increasing number of employees and then observe the impact of years of schooling. 


\section{References}

Adzic, S., Pejanovic, R. \& Medojevic, B. (in press). Education, Labor Market and Reindustrialization - Case of Serbia. Hrvatski časopis za odgoj [Croatian journal of education], 3.

Barro, R. J. \& Lee, J. W. (2001). International data on educational attainment: Updates and implications. Oxford Economic Papers, 53, 541-563.

Barro, R. J. (1991). Economic growth in a cross section of countries. Quarterly Journal of Economics, 106, 407-433. http://dx.doi.org/10.1093/oep/53.3.541

Bils, M. \& Klenow, P. J. (2000). Does schooling cause growth? American Economic Review, 90, 1160-1183. http://dx.doi.org/10.1257/aer.90.5.1160

Blanchard-Boehm, R. D. (1995). The influence of past experience with hazards on future response: a consideration for scientists and emergency managers. Journal of Academy of Business Administration, $2(1), 21-37$.

Burton, I. \& Kates, R. W. (1964). The perception of natural hazards in resource management. Natural Resources Journal, 3, 412-441.

Dewar, M. D. (1998). Do Those with More Formal Education Have Better Health Insurance Opportunities? Economics of Education Review, 17(3), 267-277.doi:10.1016/S0272-7757(97)00034-4

Epple, D. \& Lave, L. B. (1988). The role of insurance in managing natural hazard risks: private versus social decisions. Risk Analysis, 8 (3), 421-433. http://dx.doi.org/10.1111/j.1539-6924.1988.tb00507.x

Ioncica, M., Petrescu, E., Ioncica, D. \& Constantinescu, M. (2012). The role of education on consumer behavior on the insurance market. Procedia-Social and Behavioral Sciences, 46, 4154-4158.

http://dx.doi.org/10.1016/j.sbspro.2012.06.217

Lee, R. (2010). Information Filtering, Human Capital Efficiency and Economic Growth in Poor Neighborhoods. Canadian Journal of Regional Science, 33 (1), 71-82.

Ma, Y-L. \& Pope, N. (2003). Determinants of International Insurers' Participation in Foreign Non-life Markets. Journal of Risk and Insurance, 70, 235-248. http://dx.doi.org/10.1111/1539-6975.00058

Mankiw, N., Romer, D. \& Weil, D. N. (1992). A contribution to the empirics of economic growth. Quarterly Journal of Economics, 107, 407-437. http://dx.doi.org/10.2307/2118477

Montz, B. E. (1982). The effect of location on the adoption of hazard mitigation measures. The Professional Geographer, 34 (4), 416-423. http://dx.doi.org/10.1111/j.0033-0124.1982.00416.x

Moshirian, F. (1999). Sources of Growth in International Insurance Services. Journal of Multinational Financial Management, 9, 177-194. http://dx.doi.org/10.1016/S1042-444X(98)00054-1

Njegomir, V. \& Pejanović, R. (2011). Importance and current issues in agricultural insurance in Serbia. Savremena poljoprivreda [Modern Agriculture], 60 (1-2), 38-45.

Njegomir, V. \& Stojić, D. (2012). Determinants of nonlife insurance market attractiveness for foreign investments: Eastern European evidence. Economic Research, 25 (2), 297-310. 
Outreville, F. J. (2008). Foreign Affiliates of the Largest Insurance Groups: Location-Specific Advantages. Journal of Risk and Insurance, 75, 463-491. http://dx.doi.org/10.1111/j.15396975.2008.00268.x

Palm, R. I. \& Hodgson, M. E. (1992). After a California earthquake: attitude and behavior change. Chicago, IL: University of Chicago Press.

Pejanović, R. \& Njegomir, V. (2011). Problemi upravljanja rizicima u poljoprivredi [Problems of risk management in agriculture]. Ekonomika poljoprivrede [Economics of agriculture], 58 (1), 91-103.

Pulic, A. (2003). Value Creation Efficiency in the New Economy. Global Business and Economic Review, 5 (1), 111-128. http://dx.doi.org/10.1504/GBER.2003.006201

Statistical Office of the Republic of Serbia. (2012). Statistički godišnjak Srbije [Statistical Yearbook of Serbia]. Belgrade, Serbia: Author. ISSN 0351-4064

The World Bank. (2013). Agriculture, value added (\% of GDP). Retrieved February 10, 2013, from http://data.worldbank.org/indicator/NV.AGR.TOTL.ZS 